\title{
Thermal comfort monitoring in aviaries by a real-time data acquisition system
}

\author{
Tiago F. B. Camargo ${ }^{1}$, Robson L. Silva ${ }^{2}$ Márcio Higa $^{3}$, Mônica R. Coutinho ${ }^{4}$, Júlio C. D. de Oliveira ${ }^{3} \&$ \\ Wagner A. dos S. Conceição ${ }^{3}$
}

${ }^{1}$ Universidade Federal do Acre/Centro de Ciências Exatas e Tecnológicas. Rio Branco, AC, Brasil. E-mail: tiago.camargo@ufac.br - ORCID: 0000-00018880-8802

${ }^{2}$ Universidade Federal da Grande Dourados/Faculdade de Engenharia. Dourados, MS, Brasil. E-mail: rlealsilva@hotmail.com (Corresponding author) - ORCID: 0000-0002-3855-7117

${ }^{3}$ Universidade Estadual de Maringá/Departamento de Engenharia Mecânica. Maringá, PR, Brasil. E-mail: mhiga@uem.br - ORCID: 0000-0002-48258604; jcdoliveira@uem.br - ORCID: 000-0001-6794-7432; wasconceicao@gmail.com - ORCID: 0000-0003-1943-0601

${ }^{4}$ Universidade Estadual do Centro-Oeste/Departamento de Engenharia de Alimentos. Guarapuava, PR, Brasil. E-mail: monicarc77@gmail.com - ORCID: 0000-0001-9483-3000

\begin{abstract}
Thermal comfort inside broiler husbandry facilities is essential in obtaining good results in the production activity. Assessment of adequate thermodynamic conditions requires measurement and control, usually implying costs and specialized maintenance. The objective of this research was to monitor the temperature, relative humidity and air speed distributions by a developed low-cost, open-source and easyto-use measurement system, using Arduino (hardware) and Scilab (software) for real-time data acquisition. Sensors were installed in a real facility (Cianorte, PR), with measurements for internal ambient (20 sensors for temperature/relative humidity, and two sensors for differential pressure, respectively 0.5 and $1.5 \mathrm{~m} \mathrm{high}$ ) and external ambient (pressure and wind speed, $1.5 \mathrm{~m}$ high). Data acquisition system has enabled communication with sensors which are easily read by the computer and stored in a data file. The developed data acquisition system proved to be efficient when applied in a commercial broiler husbandry facility, enabling real-time monitoring for thermal comfort parameters.
\end{abstract}

Key words: measuring system, ventilation, computational fluid dynamics, poultry production

\section{Monitoramento do conforto térmico em aviários mediante sistemas de aquisição de dados em tempo real}

RESUMO: O conforto térmico no interior de instalações de criação de frangos de corte é essencial na obtenção de bons resultados nesta atividade de produção. A avaliação das condições termodinâmicas adequadas requer a medição e controle, geralmente implicando em custos e manutenção especializada. Neste trabalho, objetivou-se monitorar a distribuição de temperatura, umidade relativa e velocidade do ar utilizando sistema desenvolvido, de baixo custo, de código aberto e de fácil uso, com Arduíno (hardware) e Scilab (software) para aquisição de dados em tempo real. Os sensores foram instalados em uma unidade de produção existente (Cianorte, PR), com medições para o ambiente interno (20 sensores de temperatura/umidade e 2 sensores de pressão diferencial, respectivamente, a 0,5 e 1,5 m de altura) e para ambiente externo (pressão e velocidade do vento, a 1,5 m de altura). Sistema de aquisição de dados permitiu a comunicação com sensores, que são facilmente lidos por computador e armazenados em um arquivo de dados. O sistema de aquisição de dados desenvolvido provou-se eficiente quando aplicado em uma instalação de criação comercial de frangos de corte, permitindo o monitoramento em tempo real para os parâmetros de conforto térmico.

Palavras-chave: sistema de medição, ventilação, mecânica dos fluidos computacional, criação de aves

Ref. 193722 - Received 07 May, 2018 • Accepted 16 Jul, 2019 • Published 31 Jul, 2019 


\section{INTRODUCTION}

In confined environments, typical for breeding, thermal comfort monitoring and control are essential to ensure the health and growth; as well as proper ergonomics and human health (Carvalho et al., 2014). Energy efficiency aspects (thermal or electric) and environmental impact are also required, both related to energy use for heating or cooling, which reflect in production costs. Typical parameters for determining the thermal energy flow (heat or cold) include: dry bulb and wet bulb temperatures $\left(\mathrm{T},{ }^{\circ} \mathrm{C}\right)$, relative humidity (RH\%), air speed $\left(\mathrm{v}, \mathrm{m} \mathrm{s}^{-1}\right)$, internal and differential pressures $\left(\mathrm{P}_{\mathrm{i}}\right.$ and $\left.\Delta \mathrm{P}, \mathrm{Pa}\right)$, enthalpy $\left(\mathrm{kJ} \mathrm{kg}^{-1}\right)$; and others of specific interest: contaminants concentration and odors (air quality, e.g. ammonia and $\mathrm{CO}_{2}$ ), brightness (sunlight/natural or artificial) and ambient noise (noise pollution).

In aviculture and pig farming, an experimental approach is usually used for measurement of variables of interest (Ferraz et al., 2017). Recently it has been combined to the computational simulation (CFD) to evaluate an existing system (Coradi et al., 2016; Cordeiro et al., 2016); which can be validated by real measurements (Blanes-Vidal et al., 2008, 2010; Seo et al., 2011). Besides, combining experimental and numerical results makes it possible to evaluate any modifications, constructive or operational, to provide a better thermal comfort condition (Hernandez et al., 2016); quantitatively (lower energy consumption) and qualitatively (animal health).

Literature reports that a single measuring instrument $\left(\mathrm{HOBO}^{\circ}\right.$ data logger type sensor) at a broiler house central point was considered for temperature and $\mathrm{RH}$ data acquisition (Santos et al., 2009). In another situation (Nascimento et al., 2014), the internal environment is split into six areas, and at each center position the same measuring instrument, each one costing about 125 US\$ dollars.

Thus, the first objective of this study to use a data acquisition system of low cost, open source and easy to use (Arduino and Scilab, respectively hardware and software) for measurement and control of temperature, relative humidity, and air speed in aviaries. The proposal allows overcoming difficulties inherent to the acquisition of data on the actual situation, to achieve thermal comfort conditions over the most prolonged period possible. The second objective was to take data generated of temperature and boundary condition and, also, collected air speed to validate the developed model, carry out a computational fluid dynamics (CFD) numerical simulation with the experimental results and, in the future, propose modifications of the original system.

\section{Material ANd Methods}

Broiler husbandry facilities are in a country area at Cianorte, PR, Brazil ( $23^{\circ} 39^{\prime} 46^{\prime \prime} \mathrm{S}, 52^{\circ} 36^{\prime} 18^{\prime \prime} \mathrm{W}$, and $490 \mathrm{~m}$ of altitude). Köppen's climate classification is Cfa (temperate subtropical and warm). Poultry barn geometry and characteristics are: $6,000 \mathrm{~m}^{3}$ or $2,400 \mathrm{~m}^{2}(160 \times 15 \times 2.5 \mathrm{~m} ; 0.1 \mathrm{~m}$ bedding thickness), trees shade at the north side (10 m away), 30,000 broilers capacity, tunnel ventilation system and evaporative cooling, "Dark House"-type lighting system (low sunlight incidence) and side curtains (double and high-density liner), roof ceiling with zinc coverage and without thermal insulation. Experimental measurements took place in Autumn season (2015, April). See Figure 1.

Ventilation is through 10 axial exhaust fans (negativepressure, horizontal blades, square window $\mathrm{L}=1.4 \mathrm{~m}$ and $\mathrm{D}=1.27 \mathrm{~m}$, three-bladed, nominal flow rate $\approx 30,000 \mathrm{~m}^{3} \mathrm{~h}^{-1}$ at $\mathrm{P}_{\text {Static }}=28 \mathrm{~Pa}, 736 \mathrm{~W}$ each one) at the airflow outlet, and evaporative cooling system available at the airflow outlet (15.6 x $1.8 \mathrm{~m}$ each side, $0.15 \mathrm{~m} \times 2$ layers of honeycomb cooling pads). Each fan is turned-on/off according to demand. Lighting includes gradual control for 140 LED (5W, each).
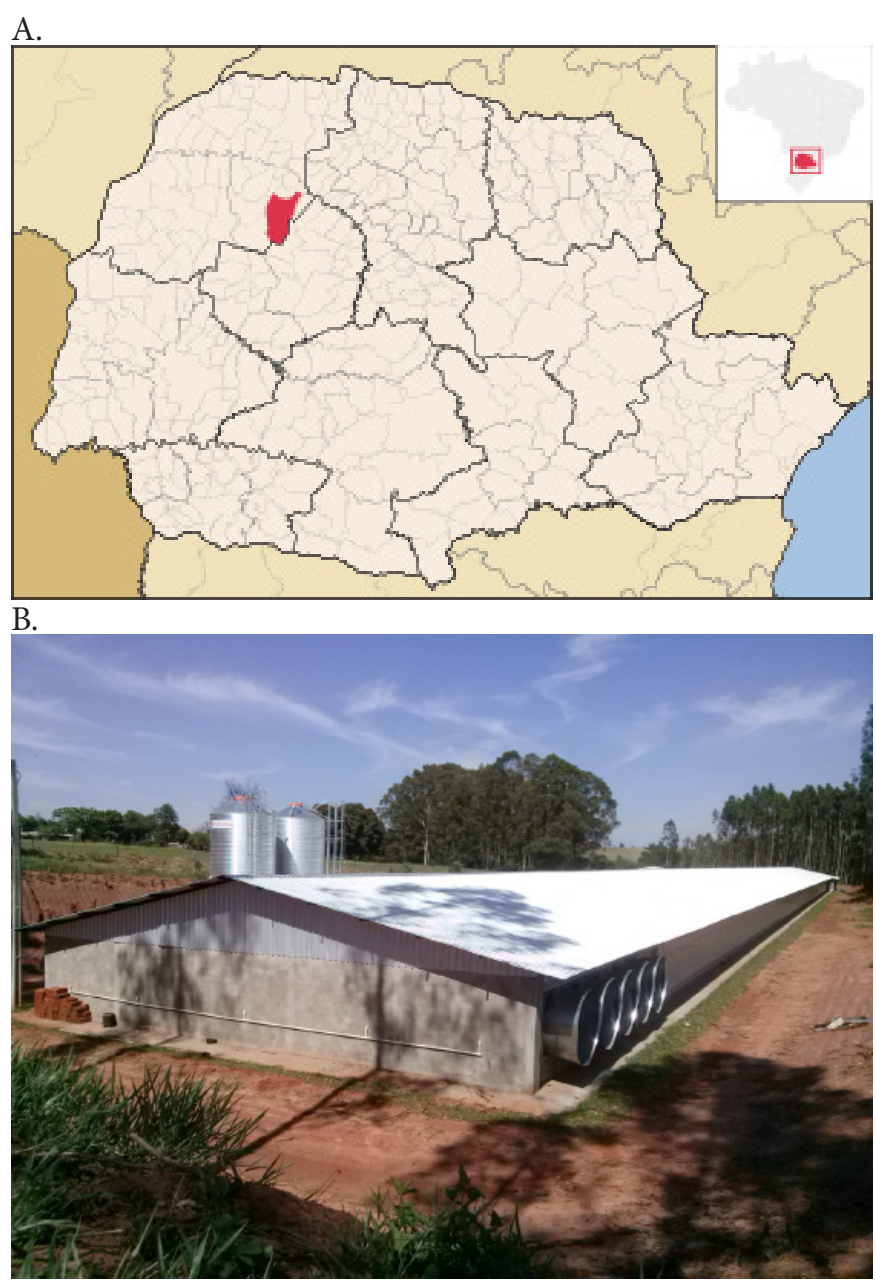

C.

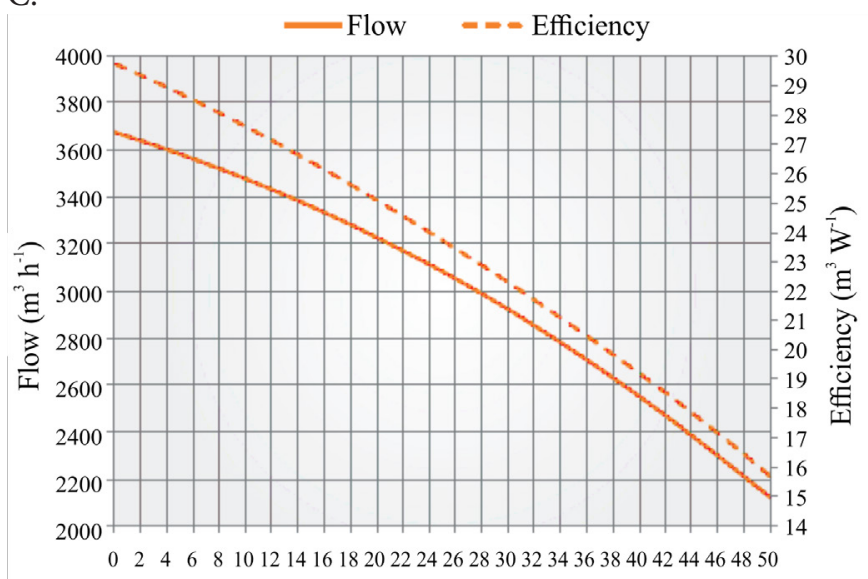

Static Pressure $(\mathrm{Pa})$

Figure 1. Geographical location in Paraná state (A), broiler husbandry facilities (B), and fan performance (C) 
Broiler weight was evaluated in 10 animals. Mass values and days of life were the following: $199 \mathrm{~g}$ (day 7), $514 \mathrm{~g}$ (day 14), $1049 \mathrm{~g}$ (day 21), $1679 \mathrm{~g}$ (day 28), $2179 \mathrm{~g}$ (day 35 or 94 of 2015 - data acquisition beginning), and $2884 \mathrm{~g}$ (day 42). Optimum temperature ranges, according to broiler development stage from its birth, are pointed out next (Fabrício, 1994): $32-35{ }^{\circ} \mathrm{C}$ ( $1^{\text {st }}$ week $), 29-32{ }^{\circ} \mathrm{C}$ ( $2^{\text {nd }}$ week $), 26-29{ }^{\circ} \mathrm{C}$ ( 3 and $4^{\text {th }}$ weeks $)$, $20-23{ }^{\circ} \mathrm{C}$ ( $5^{\text {th }}$ week $)$, and $20{ }^{\circ} \mathrm{C}\left(6\right.$ and $7^{\text {th }}$ weeks $)$; as for optimal RH, it goes from 60 to $70 \%$ at all development stages. When submitted to $\mathrm{T}>38{ }^{\circ} \mathrm{C}$ and high $\mathrm{RH}$, there is a mass decrease gain since environmental variables directly affect feed conversion efficiency and also great risk of death in birds (Abreu \& Abreu, 2011).

Instruments positioning (sites) and technical specification

Experimental measurements used sensors (Figure 2, 20 for temperature and $\mathrm{RH} ; 2$ for pressure), with recordings at $\Delta \mathrm{t}=30 \mathrm{~min}$ (pressures and wind speed with $\Delta \mathrm{t}=60 \mathrm{~min}$ ), during 7 days, positioned at $0.5 \mathrm{~m}$ (for temperature and $\mathrm{RH}$ ) and $1.5 \mathrm{~m}$ (pressure and wind speed) above the ground; thus results closer to the average level of the animals, typically 0.1-0.30 m (Coradi et al., 2016). Mean values are based on sensors registering taken almost instantly and send to Arduino for recording, as, for example, 10 records in 2 seconds or even lower. Five manual recordings for air speed were taken at each internal point (only one sensor available); methodology baseline is from literature, with adaptations, once a six-minute permanence at each site is proposed by Blanes-Vidal et al. (2008).

Adequate sensors protection was provided - given the livestock environment which can influence the measuring instruments (ex: dust). A plane parallel to the floor was selected for devices positioning; it would be possible to have included asymmetrical arrangements in the tunnel ventilation system, and even with different running conditions of the exhaust fans.

Measurement instruments' main technical specifications and uncertainties, according to information provided by the manufacturer of each device, are:

a) Temperature and RH sensors (Figure 3), model DHT22 (RHT03 or AM2302), range $-40 \sim 80\left({ }^{\circ} \mathrm{C}\right)$ and $0-100(\%)$, resolution $0.1{ }^{\circ} \mathrm{C}$ and $0.1 \%$, accuracy $\pm 0.5{ }^{\circ} \mathrm{C}$ and $\pm 2 \%$; it has intermediate cost and accuracy and is already calibrated, with cameras and adjustment coefficients stored in the sensor itself, and also compatible to Arduino platform (Jazizadeh et al., 2014).

b) Pressure sensor model BMP180 (Figure 3), range 95$105 \mathrm{kPa}\left(\right.$ at $\left.25^{\circ} \mathrm{C}\right)$, resolution $1 \mathrm{~Pa}\left(\mathrm{P}_{\text {static }}\right)$, accuracy $\pm 12 \mathrm{~Pa}$, Bosch Sensortec. Pressure values were compensated by a digital thermometer (range $0-65{ }^{\circ} \mathrm{C}$, resolution $0.1{ }^{\circ} \mathrm{C}$, accuracy $\left.\pm 0.5^{\circ} \mathrm{C}\right)$. Sensors installed near the exhaust fan and the external environment.

c) Air speed is measured with an anemometer (model: AD-250), range $0.4-30.0 \mathrm{~m} \mathrm{~s}^{-1}$, resolution $0.1 \mathrm{~m} \mathrm{~s}^{-1}$, accuracy $\pm 3 \%\left(\leq 20 \mathrm{~m} \mathrm{~s}^{-1}\right)$ or $\pm 4 \%\left(>20 \mathrm{~m} \mathrm{~s}^{-1}\right)$.

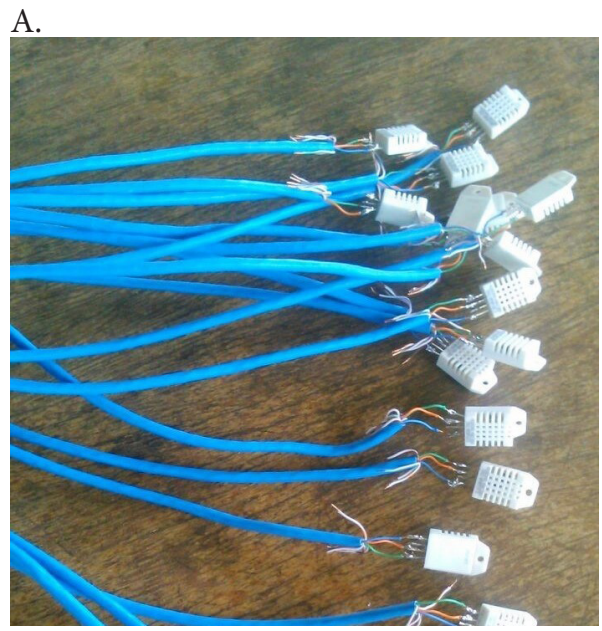

B.

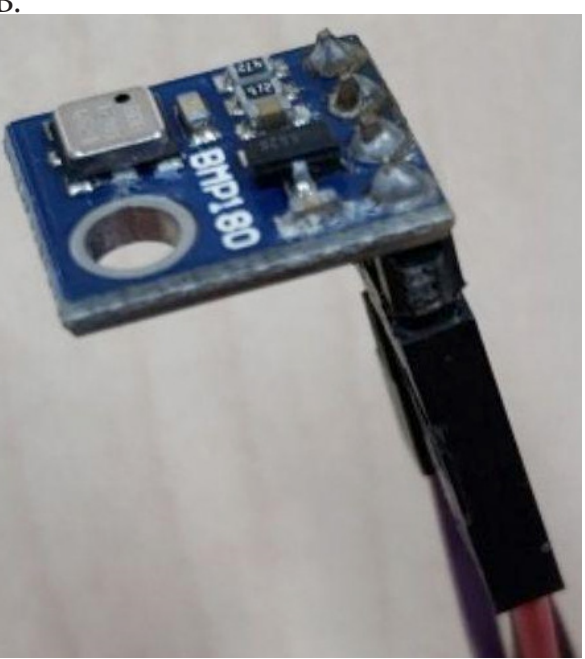

C.

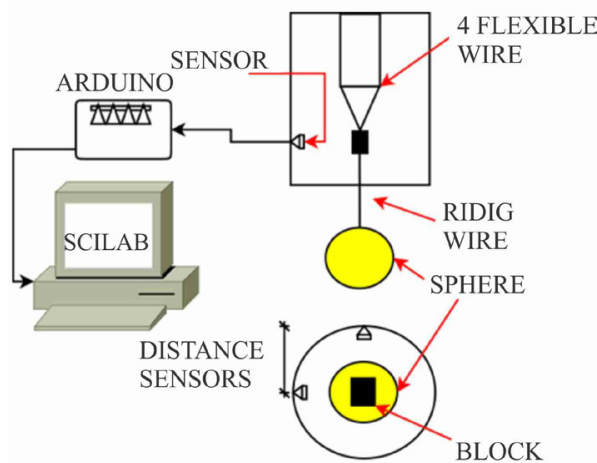

Figure 3. Temperature (A) and pressure (B) sensors, and wind speed device $(\mathrm{C})$

$2.5 \mathrm{mI} \rightleftharpoons \mathrm{W}$

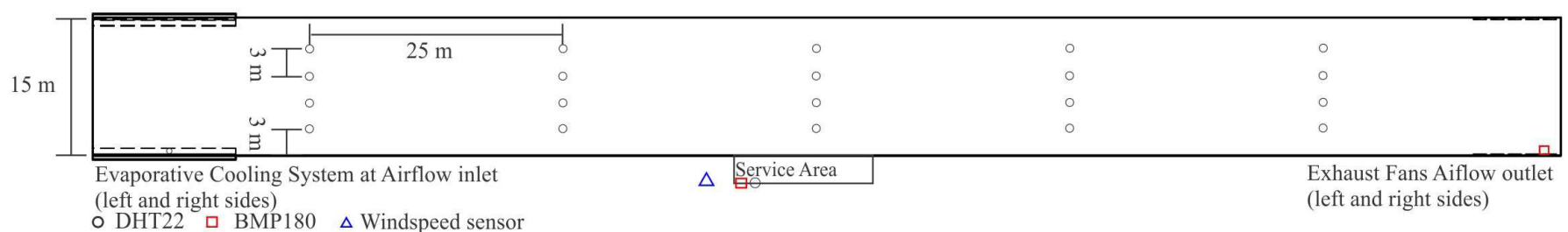

Figure 2. Sensor positioning at broiler husbandry facilities (lateral and top views) 
d) The temperature at solid surfaces (ex: walls, lining, cables, etc.), measured with a non-contact infrared thermometer (model RC002i), range $0-60{ }^{\circ} \mathrm{C}$, resolution $\pm 0.1^{\circ} \mathrm{C}$, accuracy $\pm 0.3^{\circ} \mathrm{C}$.

e) Wind speed and direction (North-South and EastWest wind velocities) measurement device was designed with two distance sensors, and low-cost apparatus to be connected to the Arduino platform (Camargo, 2015), see Figure 3. The calibration curve (range, $0.4-4.0 \mathrm{~m} \mathrm{~s}^{-1}$ ) is in two directions aligned with the two distance sensors, referenced to anemometer values (AD-250). Sensor installed at $5 \mathrm{~m}$ height.

\section{Data acquisition system (hardware and software)}

The measurement system was designed for low-cost, realtime and open-source devices (software and hardware), with suitable components. The crucial parts of a measuring system are sensors, which are devices capable of detecting and reacting to a signal (ex: electrical current), readable by a card (or Arduino). Hardware (Arduino): consists of a microcontroller board, with advantages compared to personal computers; it is low-cost, cross-platform nature (independent operating system), simple and clear programming environment, and open-source (Arduino Platform). The software SciLab is free and open-source for numerical computation (engineering applications and scientific research), compatible with many operating systems and capable of graphic constructions.

Data acquisition system consists of low-cost sensors (digital: DHT22 and BMP180; analog: QRD1114), connections and cables (CAT6, computers network type), open-source hardware and software, and data storage. Thermal comfort analysis requires proper sensors mounted to a data acquisition system able to measure the following variables: temperature, relative humidity, air speed, and pressure. Also, those variables are required to boundary conditions or samples for validation, in the computational fluid dynamics (CFD) simulation. Besides, the Arduino platform records data from sensors (analog or digital form) and can send the information elsewhere. Additional information for the system design herein presented, including communication between microcontroller and computer, data storage and processing, are available in Camargo (2015).

\section{Numerical model, CFD simulation and validation}

The temperature distribution is of utmost importance when looking for thermal comfort, as well as for validation of airflow simulation and modeling. Boundary conditions required for the computational simulation (Camargo, 2015) are: temperature and $\mathrm{RH}$ (experimental) at the airflow inlet; convection heat transfer coefficient at the floor, $\mathrm{h}=19.25 \mathrm{~W} \mathrm{~m}^{-2} \mathrm{~K}^{-1}$ (Xin et al., 2001; Seo et al., 2009); differential pressure from axial exhaust fans, $\Delta \mathrm{P}=48.7 \mathrm{~Pa}$ (when all exhaust fans are operating), Figure 1C; head loss at evaporative cooling pads; heat transfer at the walls and liners, from materials properties (Seo et al., 2009) and external temperature (experimental).

Results are for tetrahedral mesh $\left(1.5 \times 10^{6}\right.$ elements, 0.77 mean quality and 0.85 maximum obliquity), by using ANSYS Meshing (Ansys Fluent 12.0). Outlet airflow considered 7.7, 9.7 and $11.0 \mathrm{~kg} \mathrm{~s}^{-1}$ (5\% downstream turbulence; $\mathrm{Dh}=1.27 \mathrm{~m}$, hydraulic diameter). Inlet airflow considered $\Delta \mathrm{P}=0 \mathrm{~Pa}(7 \%$ turbulence intensity; $\mathrm{Dh}=2.5 \mathrm{~m})$. Liners $(6 \mathrm{~mm}$ thickness $)$ and curtains (5.16 mm thickness) considered $\mathrm{v}=0 \mathrm{~m} \mathrm{~s}^{-1}$ (non-slip condition), $10 \mathrm{~mm}$ roughness and external air temperature, except for closing walls (adiabatic as a boundary condition). For mesh details, see Camargo (2015). A CFD validation analysis was performed by NMSE - Normalized Mean Square Error methodology (Curi et al., 2017).

\section{Results AND Discussion}

Experimental results were obtained to determine the temperature, relative humidity $(\mathrm{RH})$ and air speed distribution, looking for thermal comfort conditions and computational results comparison and validation. Temperature contour fields (ANSYS CFD-Post) are from $27-34^{\circ} \mathrm{C}(300-307 \mathrm{~K})$, the maximum temperature to avoid broiler thermal stress (BlanesVidal et al., 2008). A low-cost, open-source and easy-to-use measurement system was developed, using Arduino (hardware) and Scilab (software) for real-time data acquisition, similar to other literature results (Zhang et al., 2000; Ferdoush \& Li, 2014). A method was required to measure and validate the physical quantities of the object of study (Bustamante et al., 2013; Hernandez et al., 2016).

Figure 4 indicates experimental results obtained for temperature and $\mathrm{RH}$ (288 $\mathrm{h}$ recording; $2015,94^{\text {th }}$ up to $101^{\text {st }}$ day), the main variables when determining the air thermodynamic state. Inside the husbandry facilities, temperature sensors indicate a maximum $\Delta \mathrm{T}=3.2^{\circ} \mathrm{C}$ in the whole airflow (125 $\mathrm{m}$ from the inlet to the outlet); while a maximum $\Delta \mathrm{T}=1.7^{\circ} \mathrm{C}$ occurred when comparing internal and external temperature values (Figure 4$)$. RH saturation $\left(2^{\text {nd }}\right.$ day measurements) are due to climate changes which resulted in rainy weather. Maximum temperature values (at each day) were considered as a boundary condition in the computational fluid dynamics (CFD) simulation; as well as inlet and outlet airflow data. External measurements (barometric pressure and wind speed) at the outside of the husbandry facilities were also recorded (Camargo, 2015), but no abrupt changes occurred in the period (96.1-96.5 $\mathrm{kPa}$ and wind speed $\left.<3 \mathrm{~m} \mathrm{~s}^{-1}\right)$; as well for the differential pressure at the exhaust fans $(95.2-96.0 \mathrm{kPa})$. Exhaust fans were turned on between data point 50-55 ( $4^{\text {th }}$ day experiment) when small chicks arrived in the broiler house.

Airflow speed (internal), temperature and humidity profiles, obtained from experimental data Scilab post-processing, are in Figure 5. High values for airflow speed occurs near inlet positions, because the fan deflectors direct air upwards, and then, it is again redirected downwards after reaching the roof liner. RH changes are more pronounced in the outlet (left side) than in the inlet position, likely due to an asymmetric opening of the exhaust fans (Figure 2), providing a delay between installation left and right sides. Nevertheless, the inside as a whole indicates $\mathrm{RH}$ higher than optimum values ( 60-70\%; Fabrício, 1994); as for temperature isolines, a $\Delta \mathrm{T}=2.5^{\circ} \mathrm{C}$ occurs when comparing inlet and outlet airflow positions.

Figure 6 shows a comparison, numerical versus experimental results, for airflow speed and temperature. Temperature distributions have small differences when compared to airflow 
A.

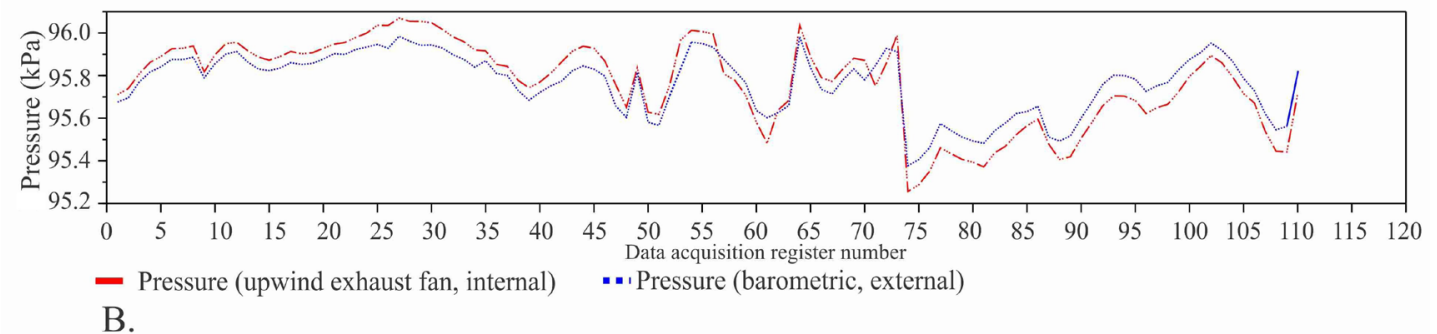

B.
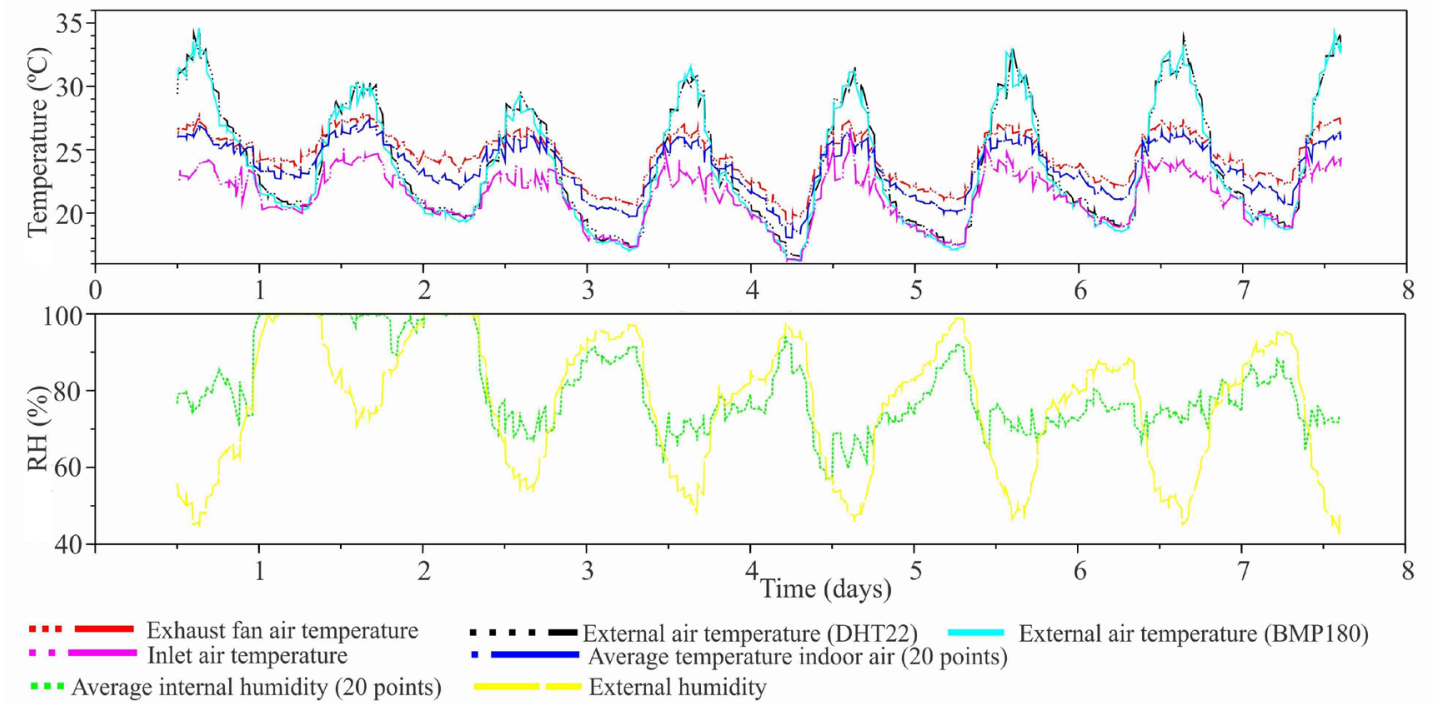

C.

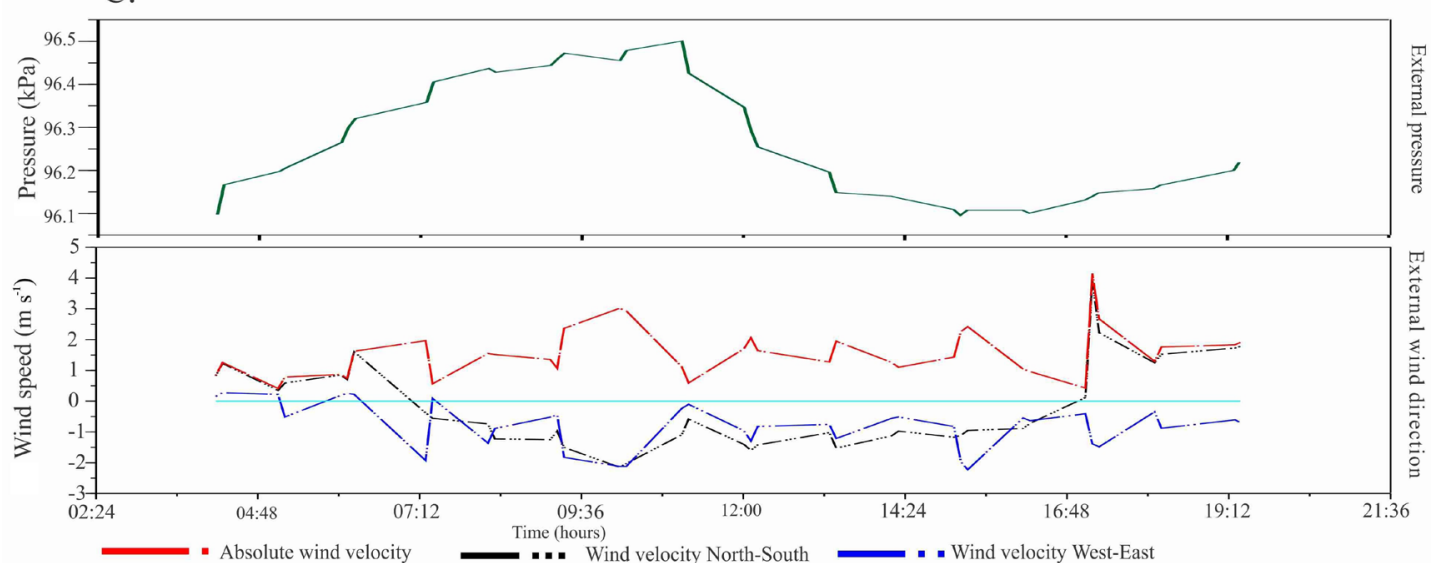

Figure 4. Pressure (A), temperature and relative humidity - RH (B), pressure and wind speed (C) during seven days of measurements

speed. For heat flux boundary conditions (Figure 6), NMSE for temperature is $\sim 1 \%\left(28.82^{\circ} \mathrm{C}\right.$ experimental versus $28.65^{\circ} \mathrm{C}$ numerical), while for airflow speed it is $\sim 15 \%\left(2.15 \mathrm{~m} \mathrm{~s}^{-1}\right.$ experimental versus $1.83 \mathrm{~m} \mathrm{~s}^{-1}$ numerical). Nevertheless, if considering the airflow at the outlet, NMSE are: $8.9 \%$ (at $7.7 \mathrm{~kg} \mathrm{~s}^{-1}$ ), $4.5 \%$ (at $9.7 \mathrm{~kg} \mathrm{~s}^{-1}$ ) and $1.8 \%$ (at $11.0 \mathrm{~kg} \mathrm{~s}^{-1}$ ). For alternative boundary conditions, convective heat transfer coefficient $\left(\mathrm{h}, \mathrm{W} \mathrm{m} \mathrm{m}^{-2} \mathrm{~K}^{-1}\right.$ ) results in higher values for NMSE in both variables; temperature is $\sim 4 \%$, and airflow speed is $\sim 22 \%$ (Camargo, 2015; for details in simulation and results). NMSE values below $25 \%$ are indicative of a good correlation between simulation and experimental results (Curi et al., 2017). Homogeneous environmental conditions can be obtained with the control of ventilation systems (Calvet et al., 2011; Bustamante et al., 2013), while literature reference values for air speed are 1.5-2.5 $\mathrm{m} \mathrm{s}^{-1}$ (Bustamante et al., 2015).
Appropriate temperature distribution, allied to its control, provide better thermal comfort. Thermal load in poultry barns is a function of internal and external aspects, such as: incident solar radiation, coverage and roof constructive material (Silva et al., 2015; Castro et al., 2017) and thermal insulation, ventilation system (natural/forced, exhaust/inflation, in tunnel/ crusade or lateral; Hernandez et al., 2016), evaporative cooling (conditioners and nebulizers existence or not; Mendes et al., 2010), and types of light control (curtains/barriers existence or not).

Recent experimental approaches to evaluate thermal comfort in broilers include: the use of thermal imaging (Nascimento et al., 2014) associated with the usual/typical variables, but requires high-cost measuring instruments and no records in real-time; obtaining thermal maps via real-time environment monitoring using 50 temperature sensors and 18 

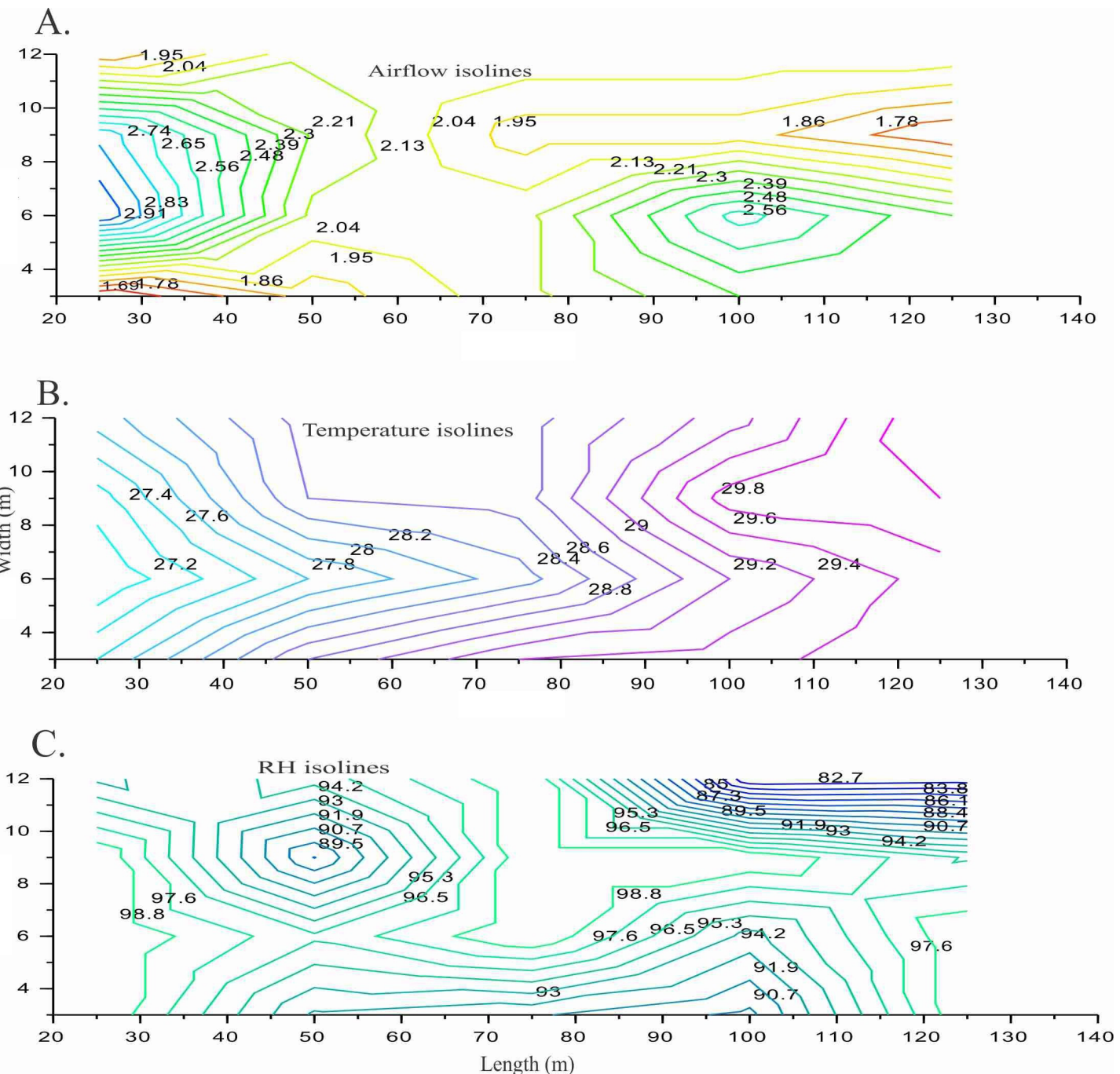

Figure 5. Isolines for airflow speed (A), temperature (B) and relative humidity - RH (C) profiles, at a maximum external temperature condition $\left(36.8^{\circ} \mathrm{C}, 13 \mathrm{~h} 56 \mathrm{~min}\right.$ local time), at the broiler husbandry facilities
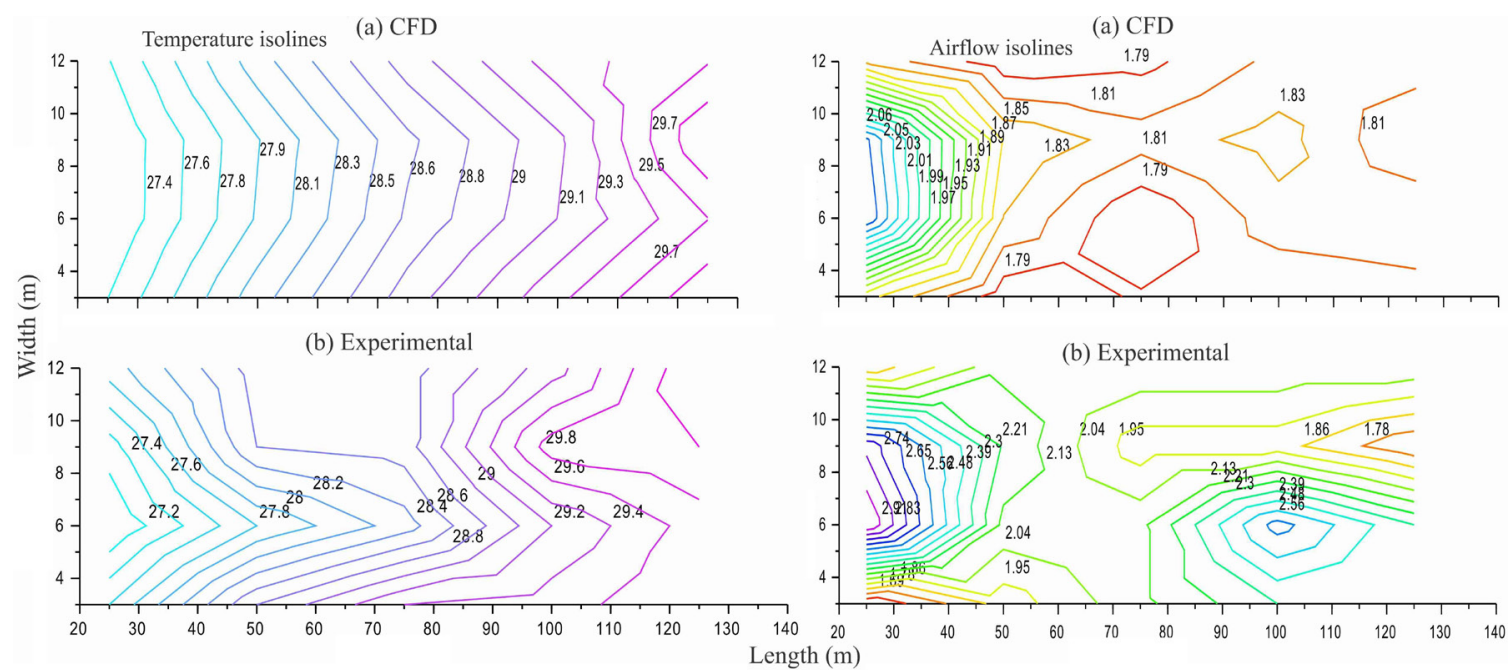

Figure 6. Temperature (left) and airflow speed (right), numerical (top) versus experimental (bottom); Boundary condition Heat flux $\left(\mathrm{q}^{\prime \prime}=81.8 \mathrm{~W} \mathrm{~m}^{-2}\right)$ and airflow $\left(\mathrm{m}=9.7 \mathrm{~kg} \mathrm{~s}^{-1} ; \mathrm{P}_{\text {outlet }}=30 \mathrm{~Pa}\right)$

for RH (Coelho et al., 2015); thermography for animal health (footpad dermatitis) enabling diagnosis of not visible injuries (Jacob et al., 2016); enthalpy mapping in poultry barns (Ferraz et al., 2016); use of LED - light emitting diodes to improve energy efficiency, i.e., lower electricity consumption, in aviaries (Thomson \& Corscadden, 2018); CFD flow simulation for ventilation systems evaluation in poultry barns (Curi et al., 2017); development and construction of PIC microcontroller (Peripherical Interface Controller) for variables supervision and control via commercial software and hardware (Proteus ISI Professional v.8 and MATLAB v. 7.8) (Alecrim et al., 2017). 


\section{Conclusions}

1. The data acquisition system is efficient, and a $2400-\mathrm{m}^{2}(125 \mathrm{~m}$ length) poultry barn requires 20 sensors to allow mapping temperature and relative humidity $(\mathrm{RH})$ distribution, thus enabling real-time monitoring for thermal comfort variables.

2. A small number of monitoring positions does not represent adequately the real thermal comfort conditions for broilers.

3. Numerical simulations provide a good approach to experimental data, considering temperature, air speed distributions and total airflow mass rates at the outlet, with normalized mean square error approximately of 1 and 15\% and less than $10 \%$, respectively.

4. Heat flux boundary conditions fitting to experimental results are better than convective heat transfer boundary conditions.

\section{ACKNowledgments}

To Coordenação de Aperfeiçoamento de Pessoal de Nível Superior (CAPES, Brazil) for granting the scholarship to the graduate program in Mechanical Engineering (PEM/UEM Universidade Estadual de Maringá). No other funding sources.

\section{Literature Cited}

Abreu, V. M. N.; Abreu, P. G. de. Os desafios da ambiência sobre os sistemas de aves no Brasil. Revista Brasileira de Zootecnia, v.40, p.1-14, 2011.

Alecrim, P. D. de; Campos, A. T.; Yanagi Junior, T.; Ferreira, J. C.; Trindade, A. A. Low cost fuzzy system applied to the control and supervision of thermal environment in poultry farms. Engenharia Agrícola, v.37, p.194-205, 2017. https://doi.org/10.1590/18094430-eng.agric.v37n1p194-205/2017

Blanes-Vidal, V.; Guijarro, E.; Balasch, S.; Torres, A. G. Application of computational fluid dynamics to the prediction of airflow in a mechanically ventilated commercial poultry building. Biosystems Engineering, v.100, p.105-116, 2008. https://doi.org/10.1016/j. biosystemseng.2008.02.004

Blanes-Vidal, V.; Guijarro, E.; Nadimi, E. S.; Torres, A. G. Development and field test of an on-line computerized instrumentation system for air velocity, temperature and differential pressure measurements in poultry houses. Spanish Journal of Agricultural Research, v.8, p.570-579, 2010. https://doi.org/10.5424/sjar/2010083-1252

Bustamante, E.; García-Diego, F.-J.; Calvet, S.; Estellés, F.; Beltrán, P.; Hospitaler, A.; Torres, A. G. Exploring ventilation efficiency in poultry buildings: The validation of computational fluid dynamics (CFD) in a cross-mechanically ventilated broiler farm. Energies, v.6, p.2605-2623, 2013. https://doi.org/10.3390/en6052605

Bustamante, E.; García-Diego, F.-J.; Calvet, S.; Torres, A. G.; Hospitaler, A. Measurement and numerical simulation of air velocity in a tunnel-ventilated broiler house. Sustainability, v.7, p.2066-2085, 2015. https://doi.org/10.3390/su7022066

Calvet, S.; Estellés, F.; Cambra-López, M.; Torres, A. G.; Weghe, H. F. A. van den. The influence of broiler activity, growth rate, and litter on carbon dioxide balances for the determination of ventilation flow rates in broiler production. Poultry Science, v.90, p.24492458, 2011. https://doi.org/10.3382/ps.2011-01580
Camargo, T. F. B. Determinação de distribuição de temperatura em aviário utilizando fluidodinâmica computacional e sistema de medição com Arduino. Maringá: Universidade Estadual de Maringá, 2015. 62p. Dissertação Mestrado

Carvalho, C. da C. S.; Santos, T. C. dos; Silva, G. C. da; Santos, L. V.; Moreira, S. de J. M.; Botelho, L. F. R. Conforto térmico animal e humano em galpões de frangos de corte no semiárido mineiro. Revista Brasileira de Engenharia Agrícola e Ambiental, v.18, p.769773, 2014. https://doi.org/10.1590/S1415-43662014000700015

Castro, A. C. de; Silva, I. J. O. da; Nazareno, A. C.; Nunes, M. L. A.; Piedade, S. M. de S. Thermal efficiency of different coverage materials in reduced models of animal husbandry facilities: A case study. Engenharia Agrícola, v.36, p.253-259, 2017.

Coelho, D. J. de R.; Tinoco, I. de F. F.; Vieira, M. de F. A.; Mendes, M. A. dos S. A.; Sousa, F. C. de; França, L. G. F. Mapeamento do ambiente térmico de aviários de postura abertos em sistema vertical de criação. Revista Brasileira de Engenharia Agrícola e Ambiental, v.19, p.996-1004, 2015. https://doi.org/10.1590/18071929/agriambi.v19n10p996-1004

Coradi, P. C.; Martins, M. A.; Costa, D. R. da; Vigoderis, R. B.; Tinôco, I. de F. F. Computational fluid dynamics (CFD) simulating heated air from wood burning inside a poultries barn. Engenharia Agrícola, v.36, p.768-778, 2016. https://doi.org/10.1590/18094430-Eng.Agric.v36n5p768-778/2016

Cordeiro, E. A. R.; Souza, S. R. L. de; Glavina, A. S. G.; Pinto, E. da S.; Bueno, L. G. de F. Simulação CFD do ambiente de instalações para frangos de corte visando o conforto térmico. Energia na Agricultura, v.31, p.342-347, 2016. https://doi.org/10.17224/ EnergAgric.2016v31n4p342-347

Curi, T. M. R. de C.; Moura, D. J. de; Massari, J. M.; Mesquita, M.; Pereira, D. F. Computational fluid dynamics (CFD) application for ventilation studies in broiler houses. Engenharia Agrícola, v.37, p.1-12, 2017. https://doi.org/10.1590/1809-4430-eng.agric. v37n1p1-12/2017

Fabrício, J. R. Influência do estresse calórico no rendimento da criação de frango de corte. In: Conferência Apinco de Ciência e Tecnologia Avícola, 1994, São Paulo. Anais... São Paulo: Apinco, 1994, p.129-133.

Ferdoush, S.; Li, X. Wireless sensor network system design using Raspberry $\mathrm{Pi}$ and Arduino for environmental monitoring applications. Procedia Computer Science, v.34, p.103-110, 2014. https://doi.org/10.1016/j.procs.2014.07.059

Ferraz, P. F. P.; Yanagi Junior, T.; Ferraz, G. A. e S.; Damasceno, F. A. Distribuição espacial do índice de temperatura do globo e umidade em galpão de frangos na primeira semana de vida aquecido por fornalha industrial. Energia na Agricultura, v.32, p.356-363, 2017. https://doi.org/10.17224/EnergAgric.2017v32n4p356-363

Ferraz, P. F. P.; Yanagi Junior, T.; Ferraz, G. A. e S.; Schiassi, L.; Campos, A. T. Spatial variability of enthalpy in broiler house during the heating phase. Revista Brasileira de Engenharia Agrícola e Ambiental, v.20, p.570-575, 2016. https://doi.org/10.1590/18071929/agriambi.v20n6p570-575

Hernandez, R. O.; Tinôco, I. de F. F.; Saraz, J. A. O.; Mendes, L. B.; Rocha, K. S. O.; Garcia, L. M. G. Thermal environment in two broiler barns during the first three weeks of age. Revista Brasileira de Engenharia Agrícola e Ambiental, v.20, p.256-262, 2016. https://doi.org/10.1590/1807-1929/agriambi.v20n3p256-262 
Jacob, F. G.; Baracho, M. dos S.; Nääs, I. de A.; Souza, R.; Salgado, D. A. The use of infrared thermography in the identification of pododermatitis in broilers. Engenharia Agrícola, v.36, p.253-259, 2016. https://doi.org/10.1590/1809-4430-Eng.Agric. v36n2p253-259/2016

Jazizadeh, F.; Ghahramani, A.; Becerik-Gerber, B.; Kichkaylo, T.; Orosz, M. User-led decentralized thermal comfort driven HVAC operations for improved efficiency in office buildings. Energy and Buildings, v.70, p.398-410, 2014. https://doi.org/10.1016/j. enbuild.2013.11.066

Mendes, A. S.; Moura, D. J. de; Nääs, I. de A.; Sonoda, L. T. Temperaturas de acionamento de sistemas de climatização para perus em épocas de baixa umidade relativa do ar. Engenharia Agrícola, v.30, p.788-798, 2010. https://doi.org/10.1590/S010069162010000500002

Nascimento, G. R. do; Nääs, I. de A.; Baracho, M. S.; Pereira, D. F.; Neves, D. P. Termografia infravermelho na estimativa de conforto térmico de frangos de corte. Revista Brasileira de Engenharia Agrícola e Ambiental, v.18, p.658-663, 2014. https:// doi.org/10.1590/S1415-43662014000600014

Santos, P. A. dos; Baeta, F. da C.; Tinôco, I. de F. F.; Albino, L. F. T.; Cecon, P. R. Ventilação em modos túnel e lateral em galpões avícolas e seus efeitos no conforto térmico, na qualidade do ar e no desempenho das aves. Revista Ceres, v.52, p.172-180, 2009.
Seo, I.-H.; Lee, I.-B.; Moon, O.-K.; Hong, S.-W.; Hwan, H.-S.; Bitog, J. P.; Kwon, K.-S.; Ye, Z.; Lee, J.-W. Modelling of internal environmental conditions in a full-scale commercial pig house containing animals. Biosystems Engineering, v.111, p.91-106, 2011. https://doi.org/10.1016/j.biosystemseng.2011.10.012

Seo, I.-H.; Lee, I.-B.; Moon, O.-K.; Kim, H.-T.; Hwang, H.-S.; Hong, S.-W.; Bitog, J. P.; Yoo, J.-I.; Kwon, K.-S.; Kim, Y.-H.; Han, J.-W. Improvement of the ventilation system of a naturally ventilated broiler house in the cold season using computational simulations. Biosystems Engineering, v.104, p.106-117, 2009. https://doi. org/10.1016/j.biosystemseng.2009.05.007

Silva, M. G. da; Martin, S.; Oliveira, C. E. G.; Moscon, E. S.; Damasceno, F. A. Desempenho térmico de coberturas no interior de modelos reduzidos de galpões avícolas. Energia na Agricultura, v.30, p.269275, 2015. https://doi.org/10.17224/EnergAgric.2015v30n3p269-275

Thomson, A.; Corscadden, K. W. Improving energy efficiency in poultry farms through LED usage: A provincial study. Energy Efficiency, v.11, p.927-938, 2018. https://doi.org/10.1007/s12053-018-9613-0 Xin, H.; Berry, I. L.; Tabler, G. T.; Costello, T. A. Heat and moisture production of poultry and their housing systems: Broilers. Transactions of the American Society of Agricultural Engineers, v.44, p.1851-1857, 2001. https://doi.org/10.13031/2013.7023

Zhang, G.; Morsing, S.; Bjerg, B.; Svidt, K.; Strøm, J. S. Test room for validation of airflow patterns estimated by computational fluid dynamics. Journal of Agricultural Engineering Research, v.76, p.141-148, 2000. https://doi.org/10.1006/jaer.2000.0538 